\title{
Electrical Conductivity and Dielectric Relaxation Processes of the Ceramic System $\mathrm{Y}_{2} \mathrm{O}_{3}-\mathrm{ZrO}_{2}-\mathrm{SrTiO}_{3}-\mathrm{BiScO}_{3}$
}

\author{
I.V. Sudzhanskaya ${ }^{1}$, V.M. Beresnev², L.O. Iliushyn ${ }^{2,3}$ \\ ${ }^{1}$ Belgorod National Research University, 85, Pobeda Str., 308015, Belgorod, Russia \\ ${ }^{2}$ V.N. Karazin National University, 4, Svobody Sq., 61022 Kharkiv, Ukraine \\ ${ }_{3}$ The University of Texas at San Antonio, Department of Physics and Astronomy, One UTSA Circle, \\ San Antonio, TX 78249, USA
}

(Received 17 April 2018; published online 25 August 2018)

\begin{abstract}
The ceramic system $\mathrm{Y}_{2} \mathrm{O}_{3}-\mathrm{ZrO}_{2}-\mathrm{SrTiO}_{3}-\mathrm{BiScO}_{3}$ was synthesized by the reaction method in the solid phase. The frequency and temperature dependences of the electrical conductivity of $\mathrm{Y}_{2} \mathrm{O}_{3}-\mathrm{ZrO}_{2}-\mathrm{SrTiO} 3-\mathrm{BiScO}_{3}$ ceramics are obtained. At a temperature above $500 \mathrm{~K}$, the dielectric relaxation of the $\mathrm{Y}_{2} \mathrm{O}_{3}-\mathrm{ZrO}_{2}-\mathrm{SrTiO}_{3}-\mathrm{BiScO}_{3}$ ceramic system was detected, the activation energy of the relaxation process was $1.25 \mathrm{eV}$. It is established that the activation energy of the conduction process of the ceramic system $\mathrm{Y}_{2} \mathrm{O}_{3}-\mathrm{ZrO}_{2}-\mathrm{SrTiO}_{3}-\mathrm{BiScO}_{3}$ was $1.04 \mathrm{eV}$.
\end{abstract}

Keywords: Electrical Conductivity, Dielectric relaxation, Ceramic system.

\section{INTRODUCTION}

At present, ceramic composites are used for the production of solid electrolytes, which meet the following criteria: high oxygen-ion conductivity, heat resistance, strength [1]. One of the basic materials corresponding to all criteria of solid electrolytes is zirconium. The use of zirconium oxide is limited by low electrical conductivity at room temperature (bandgap width $>5 \mathrm{eV}$ ) and the cubic phase is stable only at temperatures above $2570{ }^{\circ} \mathrm{C}$ [2-3]. The introduction of additives such as $\mathrm{Y}, \mathrm{Sc}, \mathrm{Mg}, \mathrm{Ca}$ allows to stabilize the cubic structure of $\mathrm{ZrO}_{2}$ at lower temperatures [4]. It is known that the $\mathrm{ZrO}_{2}-\mathrm{Sc}_{2} \mathrm{O}_{3}$ system possesses the highest conductivity from the above listed additives, but the use of such a system is limited by the degassing time, and conductivity characteristic of semiconductors is observed at temperatures of $800^{\circ} \mathrm{C}-1000{ }^{\circ} \mathrm{C}$ [5].

The introduction of an impurity of $\mathrm{Y}^{2} \mathrm{O}^{3}$ leads to an increase in the degassing time in comparison with the addition of $\mathrm{Sc}_{2} \mathrm{O}_{3}$, however, the $\mathrm{Y}_{2} \mathrm{O}_{3}-\mathrm{ZrO}_{2}$ system has a lower oxygen-ion conductivity than the $\mathrm{ZrO}_{2}-\mathrm{Sc}_{2} \mathrm{O}_{3}$ ceramic system [4]. It is known [7] that $\mathrm{Bi}_{2} \mathrm{O}_{3}$ possesses the greatest ionic conductivity, the lack of use of which is a low evaporation temperature of $700{ }^{\circ} \mathrm{C}$, and this problem can be solved by a preliminary synthesis of the $\mathrm{Bi}_{2} \mathrm{O}_{3}-\mathrm{Sc}_{2} \mathrm{O}_{3}$ system.

In addition, the film heterosystem $\mathrm{Y}_{2} \mathrm{O}_{3}-\mathrm{ZrO}_{2} / \mathrm{SrTiO}_{3}$ has a high conductivity at room temperature due to the creation of nonconducting $\mathrm{SrTiO}_{3}$ layers [8].

The synthesis of the ceramic system $\mathrm{Y}_{2} \mathrm{O}_{3}-\mathrm{ZrO}_{2}$ $\mathrm{SrTiO}_{3}-\mathrm{BiScO}_{3}$ can allow to obtain a ceramic system characterized by high oxygen-ionic conductivity.

The search for conductive ionic materials requires a detailed study of the dynamics of ion motion in a solid. Information on ohmic losses, electrochemical kinetics, mass transfer processes, and the detection of charge transfer inhibition factors can be obtained by impedance spectroscopy [9].

The purpose of this work was to study the electrical conductivity and dielectric relaxation processes of the $\mathrm{Y}_{2} \mathrm{O}_{3}-\mathrm{ZrO}_{2}-\mathrm{SrTiO}_{3}-\mathrm{BiScO}_{3}$ ceramic system by impedance spectroscopy.

\section{DESCRIPTION OF THE OBJECT AND METHODS OF THE STUDY}

Preparation of samples of composition 0.5 $\left(0.05 \mathrm{Y}_{2} \mathrm{O}_{3}-0.95 \mathrm{ZrO}_{2}\right)-0.5\left(0.6 \mathrm{SrTiO}_{3}-0.4 \mathrm{BiScO}_{3}\right)$ consisted in preliminary synthesis of $\mathrm{SrTiO}_{3}$ by annealing a mixture of strontium carbonate $\mathrm{SrCO}_{3}$ and titanium dioxide $\mathrm{TiO}_{2}$ at $1623 \mathrm{~K}$ for 2 hours. Further, a composition of $0.6 \mathrm{SrTiO}_{3}-0.4 \mathrm{BiScO}_{3}$ was obtained from a mixture of powders of synthesized strontium titanate and $\mathrm{Bi}_{2} \mathrm{O}_{3}$ and $\mathrm{Sc}_{2} \mathrm{O}_{3}$ oxides taken in the stoichiometric ratio. The mixture of powders was annealed at a temperature of $1523 \mathrm{~K}$ for 2 hours.

The obtained composition $0.6 \mathrm{SrTiO}_{3}-0.4 \mathrm{BiScO}_{3}$ and zirconium dioxide stabilized with yttrium $\mathrm{Y}_{0.05} \mathrm{Zr}_{0.95} \mathrm{O}_{2}$, taken in the stoichiometric ratio, were mixed in an agate mortar with the addition of ethyl alcohol for 4 hours, the resulting suspension was dried at $373 \mathrm{~K}$ for 1 hours. The compaction of samples with a diameter of $12 \mathrm{~mm}$, a thickness of $1 \mathrm{~mm}$, was carried out by biaxial pressing at a pressure of $70 \mathrm{MPa}$. Sintering of the samples was carried out at a temperature of $1543 \mathrm{~K}$ for 2 hours. All the processes of synthesis and sintering were carried out in an air atmosphere.

The phase composition of the obtained material was determined using a Rigaku Ultima IV X-ray diffractometer, $\sigma$ and dielectric characteristics were measured on an Novocontrol Concept 43 impedance meter using alternating current.

\section{DESCRIPTION AND ANALYSIS OF THE RESULTS}

In Fig. 1 shows the diffractogram of the ceramic system $\mathrm{Y}_{2} \mathrm{O}_{3}-\mathrm{ZrO}_{2}-\mathrm{SrTiO}_{3}-\mathrm{BiScO}_{3}$ corresponding to the presence of three phases in the system: a cubic phase with a space symmetry group Fm $3 m$ corresponding to zirconium oxide, a cubic phase with Pm3m symmetry, and a tetragonal phase with $\mathrm{P} 4 \mathrm{~mm}$ symmetry corresponding to the $\mathrm{SrTiO}_{3}-\mathrm{BiScO}_{3}$ compound. 


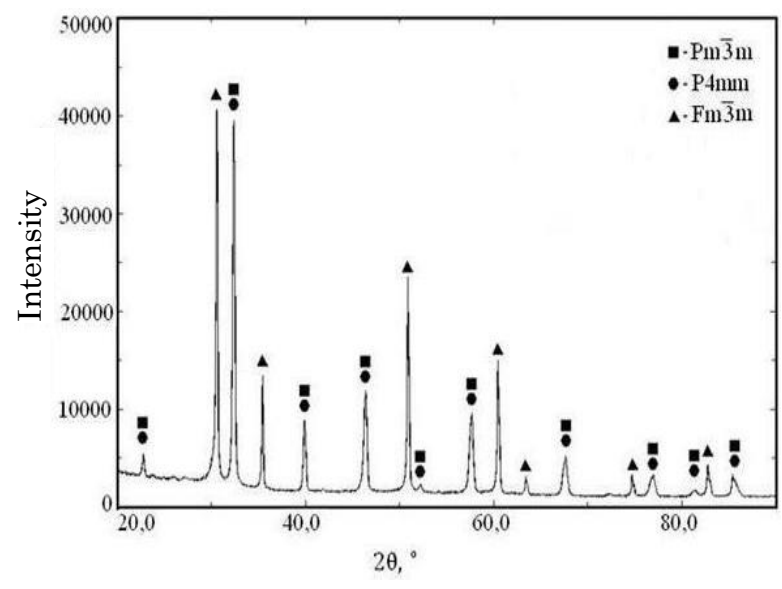

Fig. 1 - Diffractogram of the ceramic system $\mathrm{Y}_{2} \mathrm{O}_{3}-\mathrm{ZrO}_{2}$ $\mathrm{SrTiO}_{3}-\mathrm{BiScO}_{3} ; \boldsymbol{\Delta}$ - cubic $F m \overline{3} m$-phase; - - cubic Pm $\overline{3} m$ phase; $\bullet$ - tetragona $P 4 m m$-phase

In Fig. 2 the impedance spectrum constructed in the complex plane $\left(\varepsilon^{\prime \prime}=f\left(\varepsilon^{\prime}\right)\right)$, characteristic for solid solutions, is presented.

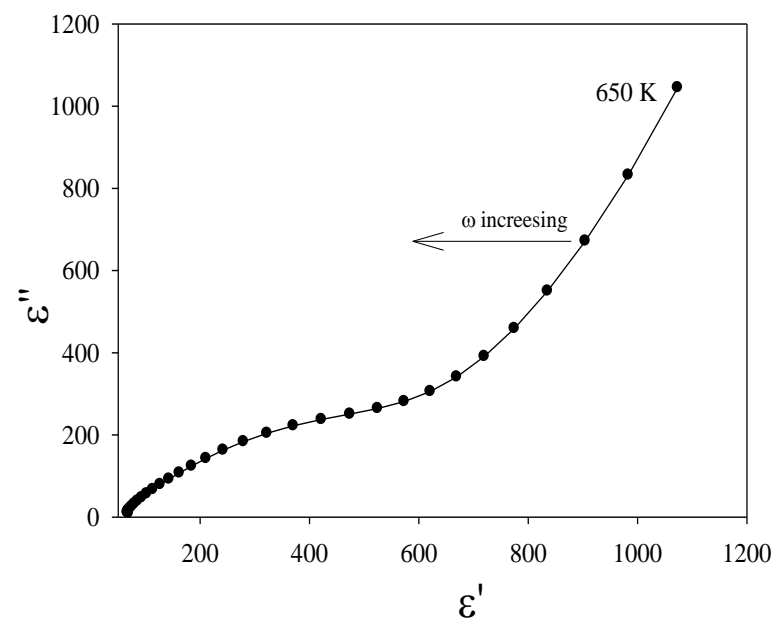

Fig. 2 - Impedance spectrum of the ceramic system $\mathrm{Y}_{2} \mathrm{O}_{3}-\mathrm{ZrO}_{2}-\mathrm{SrTiO}_{3}-\mathrm{BiScO}_{3}$, obtained at a temperature of $650 \mathrm{~K}$

Two relaxation processes are observed on the impedance spectrum: a high-frequency arc (cyclic frequency $\omega$ ), which is associated with the transport of oxygen inside the grain volume and the growth observed at low frequencies caused by the motion of oxygen ions in the concentration gradient near the solid electrolyteelectrode boundary.

It is known that the impedance spectrum of polycrystalline materials in the complex plane has two circles, indicating a contribution to the overall conductivity of the material of the grain size and their boundaries. In our case, only one circle is observed, which may be due to the high homogeneity of the samples [9].

Figure 3 shows the conductivity spectrum of $\mathrm{Y}_{2} \mathrm{O}_{3}$ $\mathrm{ZrO}_{2}-\mathrm{SrTiO}_{3}-\mathrm{BiScO}_{3}$ ceramics in alternating current as a function of frequency at different temperatures.

Analysis of the spectrum of the frequency dependence of the conductivity of the ceramic sample $\mathrm{Y}_{2} \mathrm{O}_{3}-\mathrm{ZrO}_{2}-$ $\mathrm{SrTiO}_{3}-\mathrm{BiScO}_{3}$ shows a strong dependence on the measured temperature. In the low-temperature region, a monotonous increase in the electrical conductivity is observed

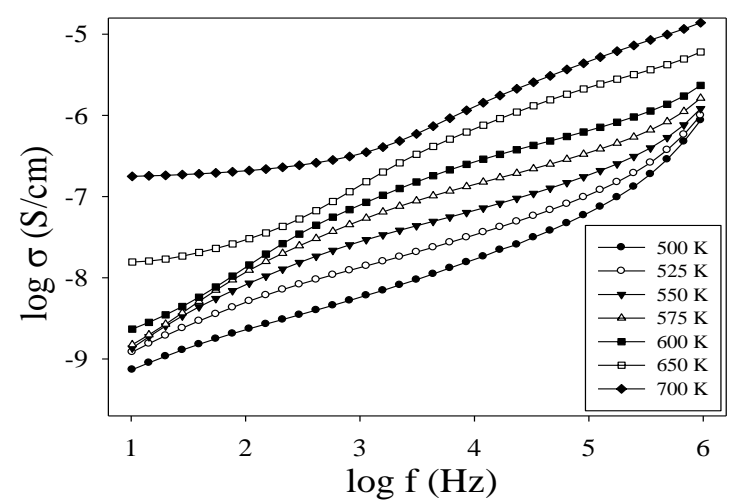

Fig. 3 - Spectrum of the frequency dependence of the electrical conductivity of the ceramic system $\mathrm{Y}_{2} \mathrm{O}_{3}-\mathrm{ZrO}_{2}-\mathrm{SrTiO}_{3}$ $\mathrm{BiScO}_{3}$ on temperature

at low frequencies, depending on the frequency, at high frequencies, the exponential dependence of the electrical conductivity on the frequency of the $\mathrm{Y}_{2} \mathrm{O}_{3}-\mathrm{ZrO}_{2}-\mathrm{SrTiO}_{3}-$ $\mathrm{BiScO}_{3}$ ceramic system.

At temperatures above $500 \mathrm{~K}$, a protrusion associated with dielectric relaxation is observed. As the temperature rises, the protrusion moves into the region of high frequencies. The presence of inhomogeneities in the frequency dependence of the specific electrical conductivity of the $\mathrm{Y}_{2} \mathrm{O}_{3}-\mathrm{ZrO}_{2}-\mathrm{SrTiO}_{3}-\mathrm{BiScO}_{3}$ ceramic system observed on the spectrum is confirmed by the results of studies of the dielectric constant and the tangent of the dielectric loss angle on frequency (Fig. 4-5).

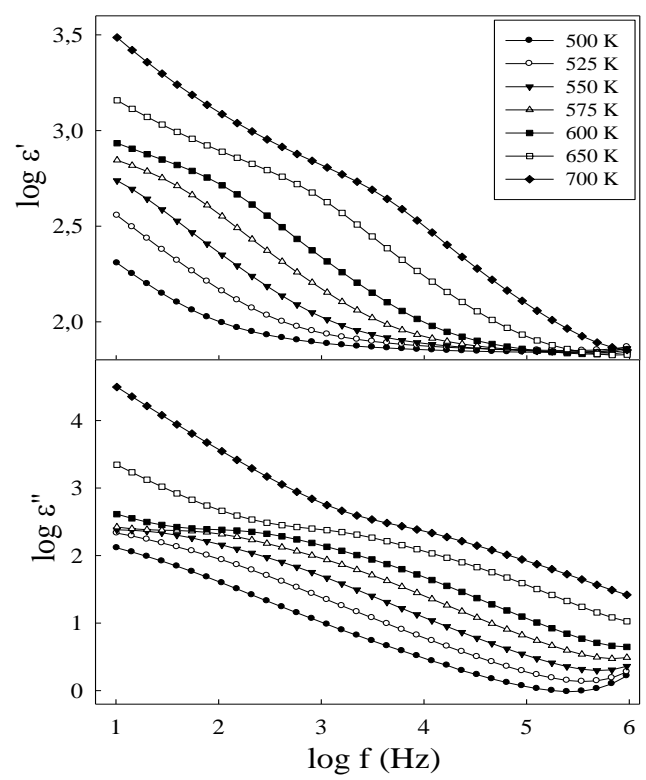

Fig. 4 -Logarithmic dependence of the imaginary $\left(\varepsilon^{\prime}\right)$ and real $(\varepsilon)$ parts of the dielectric constant of the ceramic system $\mathrm{Y}_{2} \mathrm{O}_{3}-\mathrm{ZrO}_{2}-\mathrm{SrTiO}_{3}-\mathrm{BiScO}_{3}$ on frequency

The frequency dependencies of the dielectric loss tangent (tan) of the $\mathrm{Y}_{2} \mathrm{O}_{3}-\mathrm{ZrO}_{2}-\mathrm{SrTiO}_{3}-\mathrm{BiScO}_{3}$ ceramic system at different temperatures are shown in Fig. 5.

Analysis of the frequency dependence of the dielectric loss tangent (tan) of the $\mathrm{Y}_{2} \mathrm{O}_{3}-\mathrm{ZrO}_{2}-\mathrm{SrTiO}_{3}-\mathrm{BiScO}_{3}$ ceramic system at different temperatures demonstrates the presence of a maximum whose temperature depends on the 


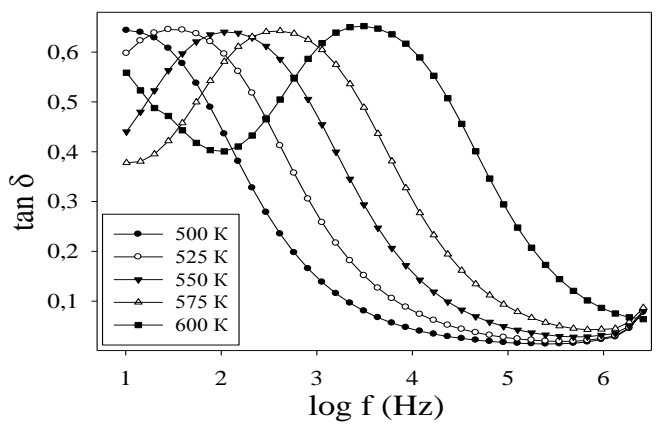

Fig. 5 - Dependence of the dielectric loss tangent (tan) of the $\mathrm{Y}_{2} \mathrm{O}_{3}-\mathrm{ZrO}_{2}-\mathrm{SrTiO}_{3}-\mathrm{BiScO}_{3}$ ceramic system at different temperatures on frequency

measured frequency-as the frequency decreases, the maximum shifts toward low temperatures. The revealed characteristics of dielectric permittivity and tangent of the dielectric loss angle are inherent in the process of dielectric relaxation.

The process of dielectric relaxation (Debye-type relaxation) is characterized by a relaxation time $(\tau)$ and an activation energy. The relaxation time is given by:

$$
\tau=\frac{1}{2 \pi f}
$$

where $f$ is the measured frequency. According to the Arrhenius law

$$
\tau=\tau_{0} \exp \left(-\frac{U}{k T}\right)
$$

where $U$ is the activation energy of the relaxation process; $k$ - the Boltzmann constant, equal to $1.38 \times 10^{-23} \mathrm{~J} / \mathrm{K}$; $\tau_{0}$ - pre-exponential factor.

The activation energy of the relaxation process, determined from the slope of the linear dependence (Fig. 6), was $1.25 \mathrm{eV}$.

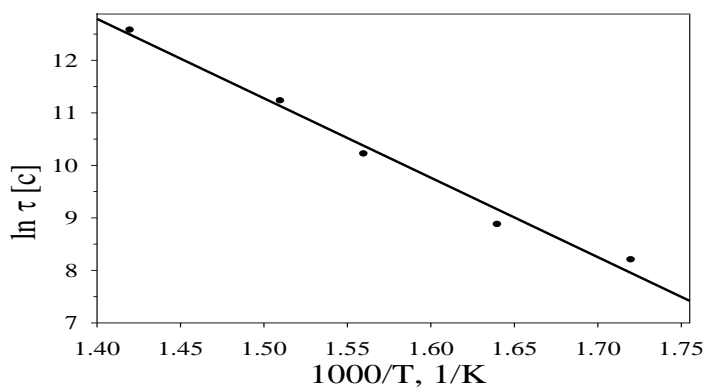

Fig. 6 - Logarithmic dependence of the relaxation time of the ceramic system $\mathrm{Y}_{2} \mathrm{O}_{3}-\mathrm{ZrO}_{2}-\mathrm{SrTiO}_{3}-\mathrm{BiScO}_{3}$ on the temperature

Figure 7 shows the temperature dependence of the electrical conductivity of the ceramic system $\mathrm{Y}_{2} \mathrm{O}_{3}-\mathrm{ZrO}_{2}$ $\mathrm{SrTiO}_{3}-\mathrm{BiScO}_{3}$ in the coordinates $\ln \sigma(1 / T)$, according to the Arrhenius law:

$$
\sigma=\sigma_{0} \exp \left(-\frac{E}{k T}\right)
$$

Where $\sigma_{0}$ is the pre-exponential factor; $E$ the activation energy of electrical conductivity;

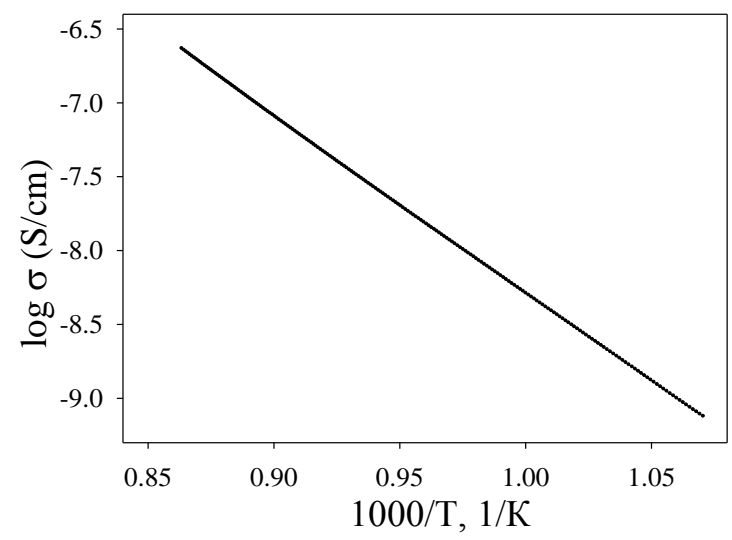

Fig. 7 - Temperature dependence of electrical conductivity of the ceramic system $\mathrm{Y}_{2} \mathrm{O}_{3}-\mathrm{ZrO}_{2}-\mathrm{SrTiO}_{3}-\mathrm{BiScO}_{3}$

The activation energy of the conduction process of the $\mathrm{Y}_{2} \mathrm{O}_{3}-\mathrm{ZrO}_{2}-\mathrm{SrTiO}_{3}-\mathrm{BiScO}_{3}$ ceramic system, calculated from the slope of the linear dependence (Fig. 7), was $1.04 \mathrm{eV}$, which makes it possible to use this system for the production of solid electrolytes.

\section{CONCLUSION}

Samples of the ceramic system $\mathrm{Y}_{2} \mathrm{O}_{3}-\mathrm{ZrO}_{2}-\mathrm{SrTiO}_{3}-$ $\mathrm{BiScO}_{3}$ are obtained. X-ray spectral analysis revealed the presence of three phases in the system: a cubic phase with a space symmetry group Fm3m corresponding to zirconium oxide, a cubic phase with Pm3m symmetry, and a tetragonal phase with $\mathrm{P} 4 \mathrm{~mm}$ symmetry corresponding to the $\mathrm{SrTiO}_{3}-\mathrm{BiScO}_{3}$ compound.

The frequency dependence of the electrical condutivity of $\mathrm{Y}_{2} \mathrm{O}_{3}-\mathrm{ZrO}_{2}-\mathrm{SrTiO}_{3}-\mathrm{BiScO}_{3}$ ceramics at different temperatures is obtained. It is shown that in the lowtemperature region at low frequencies monotonous growth of the specific electrical conductivity is observed as a function of frequency, at high frequencies - the exponential dependence of the electrical conductivity on the frequency of the ceramic system $\mathrm{Y}_{2} \mathrm{O}_{3}-\mathrm{ZrO}_{2}-\mathrm{SrTiO}_{3}-$ $\mathrm{BiScO}_{3}$. At a temperature above $500 \mathrm{~K}$, the dielectric relaxation of the $\mathrm{Y}_{2} \mathrm{O}_{3}-\mathrm{ZrO}_{2}-\mathrm{SrTiO}_{3}-\mathrm{BiScO}_{3}$ ceramic system was detected, the activation energy of the relaxation process was $1.25 \mathrm{eV}$. The activation energy of the conduction process of the ceramic system $\mathrm{Y}_{2} \mathrm{O}_{3}$ $\mathrm{ZrO}_{2}-\mathrm{SrTiO}_{3}-\mathrm{BiScO}_{3}$ was $1.04 \mathrm{eV}$.

The work was carried out using the equipment of the Joint Research Center "Technologies and Materials of the "Belgorod State University". 


\title{
Электропроводимость и процессы диэлектрической релаксации керамической системы $\mathrm{Y}_{2} \mathrm{O}_{3}-\mathrm{ZrO}_{2}-\mathrm{SrTiO}_{3}-\mathrm{BiScO}_{3}$
}

\author{
И.В. Суджанская ${ }^{1}$, В.М. Береснев², Л.А. Илюшин ${ }^{2,3}$
}

1 Белгородский государственньй национальный исследовательский университет, ул. Победь, 85, 308015 Белгород, Россия

2 Харьковский национальньй университет илени В.Н. Каразина, пл. Свободь 4, 61022 Харьков, Украина

3 The University of Texas at San Antonio, Department of Physics and Astronomy, One UTSA Circle, San Antonio, TX 78249, USA

Методом реакции в твердой фазе синтезирована керамическая система $\mathrm{Y}_{2} \mathrm{O}_{3}-\mathrm{ZrO}_{2}-\mathrm{SrTiO}_{3}-\mathrm{BiScO}_{3}$. Получены частотная и температурная зависимости электропроводности керамики $\mathrm{Y}_{2} \mathrm{O}_{3}-\mathrm{ZrO}_{2}-\mathrm{SrTiO}_{3}-\mathrm{BiScO}_{3}$. При температуре выше $500 \mathrm{~K}$ обнаружена диәлектрическая релаксация керамической системы $\mathrm{Y}_{2} \mathrm{O}_{3}-\mathrm{ZrO}{ }_{2}$ $\mathrm{SrTiO}_{3}-\mathrm{BiScO}_{3}$, энергия активации процесса релаксации составила 1,25 эВ. Установлено, что энергия активации процесса проводимости керамической системы $\mathrm{Y}_{2} \mathrm{O}_{3}-\mathrm{ZrO}_{2}-\mathrm{SrTiO}_{3}-\mathrm{BiScO}_{3}$ составила 1,04 əВ.

Ключевые слова: Электропроводимость, Диэлектрическая релаксация, Керамическая система.

\section{Електропровідність та процеси діелектричної релаксації керамічної системи $\mathrm{Y}_{2} \mathrm{O}_{3}-\mathrm{ZrO}_{2}-\mathrm{SrTiO}_{3}-\mathrm{BiScO}_{3}$}

\author{
I.В. Суджанская ${ }^{1}$, В.М. Береснев², Л.О. Ілюшин ${ }^{2,3}$
}

${ }^{1}$ Белгородський національний досліднииький університет, вул. Побєди, 85, 308015, Белгород, Росія

${ }^{2}$ Харківський національний університет ілені В.Н. Каразіна, пл. Свободи 4, 61022 Харків, Україна 3 The University of Texas at San Antonio, Department of Physics and Astronomy, One UTSA Circle, San Antonio, TX 78249, USA

\begin{abstract}
Методом реакції в твердій фазі синтезована керамічна система $\mathrm{Y}_{2} \mathrm{O}_{3}-\mathrm{ZrO}_{2}-\mathrm{SrTiO}_{3}-\mathrm{BiScO}_{3}$. Отриманочастотну та температурну залежності електропровідності кераміки $\mathrm{Y}_{2} \mathrm{O}_{3}-\mathrm{ZrO}_{2}-\mathrm{SrTiO}_{3}-\mathrm{BiScO}_{3}$. При температурівище $500 \mathrm{~K}$ виявлено діелектрична релаксація керамічної системи $\mathrm{Y}_{2} \mathrm{O}_{3}-\mathrm{ZrO}_{2}-\mathrm{SrTiO}_{3}$ $\mathrm{BiScO}_{3}$, енергія активаціїпроцесу релаксації склала $1,25 \mathrm{eB}$. Встановлено, що енергія активації процесу провідності керамічної системи $\mathrm{Y}_{2} \mathrm{O}_{3}-\mathrm{ZrO}_{2}-\mathrm{SrTiO}_{3}-\mathrm{BiScO}_{3}$ склала 1,04 еВ.
\end{abstract}

Ключові слова: Електропровідність, Діелектрична релаксація, Керамічна система

\section{СПИСОК ЛИТЕРАТУРЫ}

1. C.A. Romero, J.D. Wright. Value and Manufacturing Costs of Planar Solid Oxide Fuel Cell Stacks. GRI-96/0210 (USA, Chicago: Gas Research Institute: 1996).

2. A.V. Chadwick, Nature 408, 925 (2000).

3. J.A. Kilner, Nat. Mater. 7, 838 (2008).

4. S.P.S. Badwai, F.T. Ciacchi, Ionics 6, 1 (2000).

5. S P S Badwal, F T Ciacchi, D. Milosevic, Solid State Ionics 136-137, 91 (2000).
6. Y.H. Kim, H.G. Kim, J. Mater. Sci. Mater. Electron. 5 No 5, 260 (1994).

7. J. Garcia-Barriocanal, A. Rivera-Calzada, M. Varela, Science 321,676 (2008).

8. S.V. Gnedenkov, S.L. Sinebryukov, Vestnik of the Far East Branch of the Russian Academy of Sciences 5, 6 (2006). 